\title{
Modeling trade-offs among ecosystem services in agricultural production systems
}

\author{
Stefano Balbi ${ }^{\text {a }}$ \\ (stefano.balbi@bc3research.org) \\ Agustin del Prado ${ }^{a}$ \\ Patricia Gallejones ${ }^{a}$ \\ Chandanathil Pappachan Geevan ${ }^{\text {b }}$ \\ Guillermo Pardo ${ }^{a}$ \\ Elena Pérez-Miñana ${ }^{a}$ \\ Rosa Manrique ${ }^{c}$ \\ Cuitlahuac Hernandez-Santiago ${ }^{d}$ \\ Ferdinando Villa ${ }^{\text {a, e }}$
}

\begin{abstract}
Although agricultural ecosystems can provide humans with a wide set of benefits agricultural production system management is mainly driven by food production. As a consequence, a need to ensure food security globally has been accompanied by a significant decline in the state of ecosystems. In order to reduce negative trade-offs and identify potential synergies it is necessary to improve our understanding of the relationships between various ecosystem services (ES) as well as the impacts of farm management on ES provision. We present a spatially explicit application that captures and quantifies ES trade-offs in the crop systems of Llanada Alavesa in the Basque Country. Our analysis presents a quantitative assessment of selected ES including crop yield, water supply and quality, climate regulation and air quality. The study is conducted using semantic meta-modeling, a technique that enables flexible integration of models to overcome the service-by-service modeling approach applied traditionally in ES assessment.
\end{abstract}

Keywords: agricultural systems; ecosystem services; trade-offs; food provision; model integration

\footnotetext{
${ }^{\text {a }}$ Basque Centre for Climate Change (BC3), Alameda Urquijo 4, 4으, Bilbao, Spain.

${ }^{b}$ Centre for Environmental and Social Concerns, G-3 Samip Apt., Shreyas Crossing, Manekbaug, Ahmedabad 380015, India.

${ }^{c}$ Department of Agricultural Sciences, University of Bologna. Via. G. Fanin 50, 40127 Bologna, Italy.

d Universidad del Mar. Cd. Universitaria, Puerto Ángel, Oaxaca, México, 70902.

e IKERBASQUE, Basque Foundation for Science.
} 


\section{Introduction}

Agricultural systems constitute a source of provisioning, regulating, and cultural services ecosystem services (ES), while at the same time depend highly on them in order to function (Power, 2010). Furthermore, certain agricultural management practices greatly impact service-producing ecosystems, as in the case of intensive farming or intensified food production (Arriagada and Perrings, 2011; Godfray et al., 2010; Kleijn et al., 2006). The delivery of ES by agricultural ecosystems becomes increasingly important as demand for food brings new areas of land under agricultural management and the attempts to raise crop yield intensify, while increasing urbanization and land degradation reduce agricultural land availability. Along with the growing need to ensure food security globally, there has been a significant decline in the state of ecosystems and the services they provide (FAO, 2007; Steinfeld et al., 2006; Thiaw et al., 2011). The Millennium Ecosystem Assessment (MA, 2005) highlighted trends of significant decline in many ES of high relevance to food security, especially those provided by cultivated ecosystems.

In order to reduce negative trade-offs and identify more sustainable management scenarios, it is necessary to improve our understanding of the relationships between various ES (Bennett et al., 2009). The integration of ecological and agronomic factors is necessary to account for the complexity of cropping systems (Athanasiadis et al., 2007) and its important consequences. This complexity arises at multiple scales in both space and time, resulting from the interplay of biotic and abiotic factors under the effect of both global and regional change (Schröder, 2006). The interplay of human and natural capital represented in current agricultural systems determines multiple interdependencies between natural and anthropogenic elements; these should not be ignored if the ultimate goal is sustainable production.

A broader ecosystem-based approach to food security has been advocated to avoid major negative repercussions to human societies (Richardson, 2010; Steinfeld et al., 2006; Thiaw et al., 2011; Poppy et al., 2014). Such a shift cannot happen without methods that can make scientifically sound knowledge available to natural resource decision makers (Tallis and Polasky, 2009). While sophisticated simulation models of crop production have been developed, most of them do not account for the whole range of ES, and only very few incorporate spatial aspects with an emphasis comparable to what modern ES science considers crucial (Bagstad et al., 2013a; Villa et al., 2014). Earlier agricultural system models focusing on individual processes have later adopted a more holistic system dynamics approach (Belcher et al., 2004) but stopped short of becoming spatially explicit and of incorporating more fully ES-relevant processes. Examples of such models are EPIC (Williams et al., 1985); CERES (Ritchie et al., 1986); CREAMS/GLEAMS (Knisel, 1980; Leonard and Knisel, 1987); CENTURY (Metherell et al., 1993; Parton et al., 1987) and APSIM (Holzworth et al., 2014).

More recent studies have attempted to address agro-ecosystem sustainability by integrating multiple models representing agricultural systems in a multi- or inter-disciplinary manner (e.g. Jones et al., 2003) and, in a few cases, have shown the ability to generate spatially explicit outputs by connecting to geographical information systems (GIS) (e.g. Lorenz et al., 2011; Koschke et al., 2013). Such results exemplify the usefulness of pursuing an integrated approach to the management of certain ES affecting agricultural systems. These approaches often link existing models dynamically or through meta-modeling (Lotze-Campen et al., 2008). However, significant challenges remain. Firstly, attempts to model non-linear systems are hampered both by lack of data and the difficulty of accounting for integrated response relationships, pointing to the need to capture uncertainties in both quantitative and qualitative information. Secondly, generating reliable solutions for multidisciplinary problems is rarely possible with just one type of model. Deep model integration combined with model inter-comparison rules is therefore necessary. 
This article describes the application of the semantic meta-modeling approach (Villa et al., 2014) to the study of ES trade-offs connected with agricultural production and food provision. The importance of ES and the need for a deeper understanding of their relationships with agricultural systems are explained further in this section. In Section 2 we introduce the methodological premises of our approach, we describe the regional context of analysis and the sub-models composing the integrated model. After illustrating results of sensitivity analysis for the Bayesian model employed, Section 3 presents the results of modeling scenarios of relevance for the region, both in an aggregated and a spatially explicit fashion. The concluding Section 4 discusses the results in the light of the methodology employed, highlighting key messages and listing some of the issues not addressed in this paper for further investigation.

\subsection{Ecosystem services: foundations}

As early as the middle of the 19th century, several prominent naturalists, ecologists and economists began to recognize the "life-support" functions of ecosystems (Coase, 1960; Helliwell, 1969; Krutilla, 1967). By the 1970s the term "environmental services" was being used to describe benefits people receive from well-functioning ecosystems, such as food, pest control, flood control, climate regulation, and recreation (Meyerson et al., 2005). Despite a rapid increase in studies of ecosystem goods and services, a systematic typology and comprehensive framework for integrated assessment and valuation of ecosystem functions has been slow to emerge (De Groot, 2002). A structured approach to ES was successfully used in the Millennium Ecosystem Assessment (MA, 2005) which integrates the discourse on biodiversity conservation and sustainable development (Tallis et al., 2008). The definition of Ecosystem Services used in the MA, now widely adopted, is the starting point for the refined perspective brought forth by the global initiative "The Economics of Ecosystems and Biodiversity" (TEEB), which defines ES as the "flows of value to human societies as a result of the state and quantity of natural capital" (TEEB, 2010). The key MA (2005) findings noted that over $60 \%$ of ES were already globally degraded and 15 of the 24 ES investigated were in a state of decline, with negative implications for human welfare.

The MA (2005) recognized four categories of ES:

1. Supporting (e.g. nutrient cycling, soil formation and primary production);

2. Provisioning (e.g. food, fresh water, wood and fibre and fuel);

3. Regulating (e.g. climate regulation, flood and disease regulation and water purification); and

4. Cultural (aesthetic, spiritual, educational and recreational).

Supporting services comprise the ecological functions necessary for the production of all other ecosystem services. Provisioning services that are generated by ecosystems are usually harvested for use by people. Regulating services are the "eco-physiological functions and ecosystem processes" necessary to maintain the functioning of ecosystems, and they directly or indirectly regulate the production of provisioning services. Cultural services represent non-material benefits and nonconsumptive use values derived from ecosystems (Elmqvist et al., 2011). More recently (e.g. HainesYoung and Potschin, 2010), the "supporting services" category has been recognized as flawed due to the potential for "double counting" of service values (Boyd and Banzhaf, 2007; Wallace, 2007; Fisher et al., 2008) and it is being abandoned in favor of a more beneficiary-related perspective (Villa et al., 2014).

The concept of ES clearly implies an anthropocentric perspective although ecosystem functions encompass different combinations of processes, traits and structures and represent the potential that ecosystems have to deliver services, irrespective of their utility to humans (Braat and De Groot, 2012). At the same time, the metrics used to assess the potential of ecosystems to provide services and to determine the levels of services that are provided as benefits to humans can also be used to assess the health of ecosystems per se (Palmer and Febria, 2012; Haines-Young and Potschin, 2010). 


\subsection{Ecosystem services and agricultural systems}

MA (2005) notes that by 1990, 35\% of the Earth's land surface was being used for agriculture. Conservative estimates reveal that globally, approximately six million hectares of land are converted from natural state to crop land every year (Deininger and Byerlee, 2011). Nevertheless, because land is a non-renewable resource, extensive use of land for agriculture severely affects the generation of many other ES. Indeed, the expansion of modern agriculture, including livestock rearing, is a major driver of global environmental change, through impacts on land use, land cover, water balance, water quality, pollination, nutrient cycling, soil retention, carbon sequestration, climate regulation and biodiversity (FAO, 2007; Gordon et al., 2010; Nellemann, 2009).

Some of the detrimental impacts discussed in the literature are:

1. The effect on the availability and mobility of nutrients over large regions of the Earth due to the massive use of nitrogen and phosphorus fertilizers (Vitousek et al., 1997) and the subsequent pollution of air, water and land, causing human health problems (Galloway et al., 2004; Sutton et al., 2013);

2. The damage to productive land brought by soil erosion and degradation, causing food insecurity, where access to nutrients is scarce or where extensive tillage is practiced, especially when combined with removal or in situ burning of crop residues (Verhulst et al., 2010);

3. The contribution to $19 \%-29 \%$ of global anthropogenic greenhouse gas (GHG) emissions primarily through methane and nitrous oxide emissions (IPCC, 2007; Vermeulen et al., 2012) and secondarily through the use of fossil fuel for fertilizer production (Glendining et al., 2009);

4. The effect on water resources: water withdrawals from rivers and lakes doubled globally since 1960, of which almost $70 \%$ was used for irrigation (MA, 2005).

These impacts are likely to become exacerbated in the future, with ongoing population growth and a growing middle class that will determine an increasing demand for food. The 2012 revision of the official United Nations population estimates and projections indicates that the world population of 7.2 billion, in mid-2013, will be almost 8.1 billion in 2025, 9.6 billion in 2050 and 10.9 billion by 2100 (UN, 2013). According to Bruinsma (2009) an expected population increase to 9 billion translates to an additional need per year of nearly one billion tonnes of cereals and 200 million tonnes of livestock products as compared to 2007. Under the MA (2005) scenarios, the projected demand for food crops could grow by $70 \%$ to $85 \%$ in the next five decades, with a global water demand increasing by $30 \%$ to $85 \%$ (see also Brown, 2012).

Given the high interdependence of global food security and numerous ES, it is critical to develop a deeper understanding of their relations (Richardson, 2010). The global challenge of food security raises the question of how to sustain various interconnected ES (Thiaw et al., 2011). Besides yield potential, integrated models need to examine other dimensions such as biodiversity conservation, land degradation, pollination, pest and disease control, water resources (quality and quantity), climate regulation, air quality, recreation and cultural diversity, and lifecycle maintenance (Bommarco et al., 2013). In particular, it seems essential to understand how agricultural management practices impact natural capital stocks and thereby provision of ES, considering the synergies and the trade-offs between them (Foley et al., 2005; Raudsepp-Hearne et al., 2010).

To our knowledge only a limited number of studies (e.g. Pilgrim et al., 2010; Potts et al., 2009; Elmqvist et al., 2011; Pretty et al., 2006) have demonstrated the capacity of conducting integrated analyses on the effects, both positive and negative, that agriculture systems have on ES. Regardless of specific cases the yield maximisation paradigm which is often promoted at the farm level can produce inefficient results under a perspective where multiple ES are considered. It is therefore of crucial importance to quantify trade-offs between agricultural production and other ES to better inform policy decision making. 
Understanding complex relationships between ecosystem functions and the resulting services must tackle change and uncertainty for instance through scenario and sensitivity analysis. ES in general depend on the interaction of multiple ecosystem types at different temporal and spatial scales, characterised by non-linear relationships (Bennett et al., 2009; Burkett et al., 2005; Koch et al., 2009), which can only be partially described by statistical analysis (Sun and Müller, 2013). Agricultural landscapes are dynamic, subject to variable climatic conditions, unstable ecological processes and changing management practices. Yet, dynamic simulation models have been used in a limited way, mostly to address isolated processes and only rarely examining how agricultural practices affect multiple ecosystems (Barraquand and Martinet, 2011).

The high dependence of ES delivery on geographical location, the demand for ES and the characteristics of benefitting areas have spurred the development of spatially explicit assessment methods (Nelson et al., 2009; Parra-López et al., 2008; Fisher et al., 2011; Potschin and HainesYoung, 2011, Bagstad et al., 2013a; Villa et al., 2014 ). Various typologies of data, including spatial data, have to be considered to understand how increasing one service will impact on other services provided by the same area or adjacent areas (Maes et al., 2012). Furthermore, just like the flow of ES from agriculture may depend on services provided by neighboring ecosystems, the activities on one farm may also alter the delivery of services to other farms (Power, 2010). It is, therefore, important to monitor agriculture at different scales, starting with the effect of practices at farm level, and developing procedures that allow the integration of results at larger scales. This will provide the information needed to design appropriate policies to promote sustainable practices (Van Keulen et al., 2000; Pérez-Miñana et al., 2012).

It is increasingly clear that the dominant "one model fits all" paradigm is often ill-suited to address the diversity of real-world management situations that exist across the broad spectrum of coupled natural-human systems (Villa et al., 2014). Methods are necessary that can integrate different modeling techniques and types of knowledge, including multiple quantitative and semi-quantitative data sources and expert opinion.

An additional step in this direction is provided by the recent development of methods that aim at including human agency within ecosystems dynamics. The need for modeling techniques that can consider the heterogeneous behaviour of human agents affecting the agricultural systems at different scales is highlighted in several works where agent-based methods are used to explore the dependencies between population density, agricultural intensity, market influence, risk attitude and environmental incentives (Balbi et al., 2013; Magliocca et al., 2013; Sun and Müller, 2013).

\section{Material and Methods}

\subsection{ES flows and the ARIES framework}

Traditionally, frameworks to account for the value of ES have been structured around three main components: (i) measuring the provision of ES; (ii) determining their monetary value; (iii) designing policy tools for their management (Boyd and Banzhaf, 2007; Polasky, 2008; Dominati et al, 2010). However, such frameworks have been challenged for their inadequate understanding of the specifics of what these services constitute and for market failures in capturing their value (Daily et al., 2009). Flows of ecosystem services connect stocks of natural capital produced by ecosystems to societal groups that need them. In order for such flows to exist, the capability of the ecosystem to produce benefits needs to be complemented with that of delivering them. A degraded or declining ecosystem would experience both reduced production and reduced ability to sustain the flow of benefits (Layke, 2009; Bagstad et al., 2013a). Ecosystem services consist of flows of materials, energy, and information from natural capital stocks that combine with manufactured and human capital services to produce or sustain human welfare. Attention to flow dynamics in ES has been advocated for some time but only recently integrated in ES modeling (Bagstad et al., 2013a; Villa et al., 2014). 
In order to address ecosystem service flows in a consistent manner, and avoid the problem of double counting, Villa et al. (2014) adopt an approach that includes five key components:

1. The ES beneficiaries who gain from the "ecological endpoints" (Boyd and Banzhaf, 2007) or "final ecosystem goods and services" (Johnston and Russell, 2011);

2. The carrier, for each benefit type expressed in physical units or relative rankings, that transmits the service by connecting ecosystems and people (e.g. Kg of crop yield when referred to food provision);

3. The carrier type, because depending on the use of or contact with the carrier, from a human perspective, it can be beneficial or detrimental;

4. The use of the carrier, further classified as rival or non-rival, and its sources, sinks, or use as biophysically limited or unlimited; and

5. The flow type used in routing the carrier from ecosystems to people - or for some servicesrouting people to ecosystems.

Each of these elements is built using data and models derived from the context of interest. These models quantify and map source locations (ecosystems that generate an ecosystem service carrier), sink locations (landscape features that can absorb, degrade, or deplete a carrier), and use locations (human beneficiaries of the service), connecting these areas to quantify service flows.

The implementation of this theoretical framework, as used in the Artificial Intelligence for Ecosystem Services (ARIES) methodology, is a spatially explicit, semantic meta-modeling platform built using artificial intelligence techniques (Villa, 2007; Villa et al., 2014). In this framework, ES are expressed in terms of their effects on human well-being which are derived through the flow of benefits from an ecosystem endpoint to a human endpoint at given extents of space and time. The implementation combines spatially explicit models of ES provision and use with dynamic flow models describing the distribution of benefits across a specific landscape. The exact form of the models depends on the specific context of application and is dynamically generated by means of machine reasoning techniques, operating on data and ontological connotations of the services (e.g. the rival/non-rival nature of the benefits for their human beneficiaries, or the "provisioning" character of the services). The uncertainty associated to the decision-making process is expressed and managed in the modeling environment using probabilistic models such as spatial Bayesian networks (McCann et al., 2006). The different components representing providers, users or sinks for ES, are connected depending on the "direction of flow" of the carrier. This enables a dynamic flow analysis in which it is possible to identify the spatial pathways of provision of each ES from point of provision to point of use.

The development of decision support tools similar to ARIES that integrate ecology, economics, and geography to support decision making in different application areas is a fairly recent phenomenon (Daily et al. 2009; Ruhl et al., 2007), and there is great variety in the levels of complexity and sophistication adopted. A review of the state of the art can be found in Bagstad et al. (2013b).

\subsection{Model description}

Our model was developed to capture important ES trade-offs in a generic agricultural landscape. In this paper we use the case study of Llanada Alavesa, located in the Basque Country, Northern Spain, as a demonstration. Needs expressed by the regional authorities, in conjunction with a consolidated direct knowledge of the region by some of the authors, were the rationale for the choice of location. Llanada Alavesa consists of wide flatlands surrounded by mountains to the south and the north. The main land use types are natural forest (38\%) and agriculture (35\%), with some semi-natural grassland between the two zones. The agricultural surface is predominantly (92\%) composed of rainfed cereal crops (wheat, barley, oat), and some irrigated potato and sugar beet cultivations.

Application of manure and fertilizer is restricted in about $30 \%$ of the land to comply with legislation on nitrate vulnerability (BOPV, 2008). The climate is temperate-humid Mediterranean, with warm 
summers and cold winters, representing the transition between the humid oceanic conditions in the North of Spain and the drier Mediterranean climate of the Southern region.

Our model analyses the effects of both farming practices and local environmental conditions on several $\mathrm{ES}^{1}$ of major importance within the case study area:

1. Crop production (winter wheat yield);

2. Water quality (associated with nitrate leaching and phosphorus losses from the agricultural soil);

3. Climate regulation (associated with soil carbon storage and nitrous oxide emissions);

4. Air quality (associated with ammonia pollution).

Farming practices considered include irrigation, tillage, and application of both organic and mineral fertilizers. Environmental conditions considered include soil characteristics, precipitation and above ground temperature. Fig. 1 illustrates the conceptual model in more detail.

Each ES is developed as a stand-alone module, but all the modules share input variables and are linked by the infrastructure, making the overall model responsive to scenarios in an integrated way. Choices of farming practices and environmental conditions can affect the ES production in non-trivial ways. For example, increasing the use of fertilizer affects crop yield positively but it also affects climate regulation services negatively through the indirect emissions derived from the manufacturing of the fertilizer, which results in an increase to the sector's total carbon dioxide $\left(\mathrm{CO}_{2}\right)$ footprint.

In addition to being sensitive to the same inputs, different ES have interdependencies that are at the source of more trade-offs. For example, increased crop yield will negatively affect climate regulation services through an increase of soil nitrous oxide $\left(\mathrm{N}_{2} \mathrm{O}\right)$ emissions due to larger amounts of plant residue. Other interactions expressed in the model are:

- The effect of water supply on crop yield, represented as rain and irrigation (the model does not consider the case of floods);

- The effect of soil water on ammonia $\left(\mathrm{NH}_{3}\right)$ emissions.

The model was written for the ARIES system by coding each sub-model in the Thinklab language (Villa et al., 2014). Each ES module was independently developed by different authors, without regard to the resolution or even the spatially explicit nature of the inputs, but simply with an agreement on the semantics of the intended inputs and outputs (Madin et al., 2008; Villa et al., 2009). The mutual effects of ES on one another were stated as semantic dependencies in the modules, which were turned into input/output relationships when the final integrated model was assembled by the infrastructure, connecting models to data and models to models.

Some of the modules have a deterministic character, using equations and look-up tables derived from the literature ${ }^{2}$. Other modules are probabilistic Bayesian networks calibrated on empirical data (e.g. the crop yield module). The infrastructure negotiates the interaction of deterministic and probabilistic models, submitting the output of the first as evidence to the second. Bayesian network models were developed using the Genie software (http://genie.sis.pitt.edu/) and run within ARIES, which directly supports Genie's native format and can transparently integrate the models with the remaining components on the basis of stated semantic annotations (Villa et al., 2009).

In the following sub-sections we describe each module in detail. All the modules interact at the pixel level; lateral exchanges mediated by hydrological transport were ignored because of their lack of relevance in this largely flat region. The final models and scenarios were run on a raster grid of $444 x$

\footnotetext{
${ }^{1}$ Additional details on the relation between model output variables and ES as per the ARIES framework (Bagstad et al., 2013a) are included into the Appendix (Table A1).

${ }^{2}$ A quick description of each module is given in the Appendix (Table A1), while the related BN can be accessed online (link provided in the Appendix).
} 
190 cells, with a spatial resolution of 200 m. All scenarios described in Section 3.2 were coded in Thinklab and run in sequence.

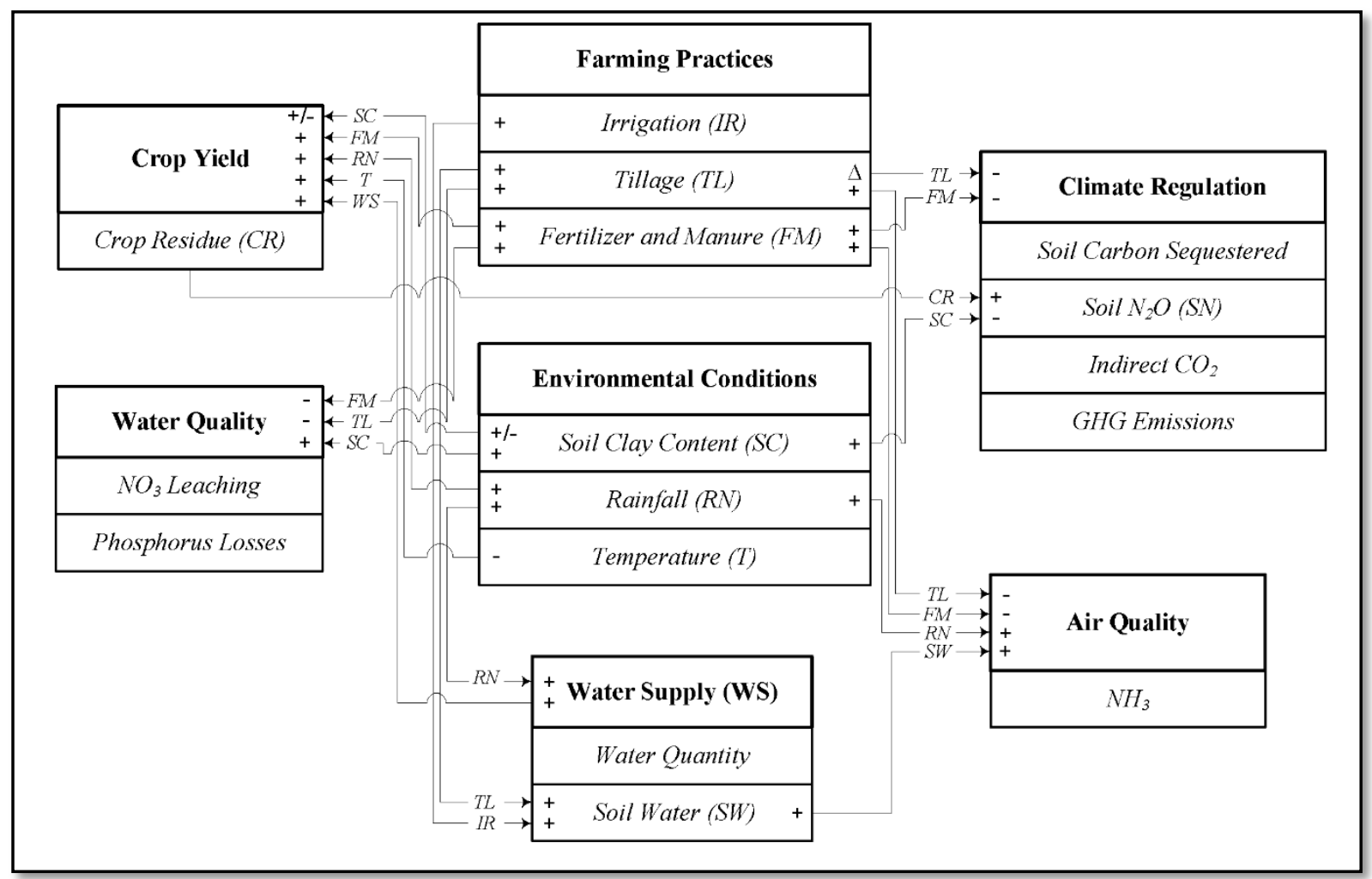

Fig. 1. Conceptual model adopted for this study. Rectangles in bold line represent main model components and regular rectangles sub-modules, each label includes an acronym that is used to identify the interactions. The sign "+" means "More of"; the sign "-" corresponds to "Less of"; and the delta symbol " $\Delta$ " should be read as "Change in (tillage practice)".

\subsubsection{Agricultural production}

The agricultural production module describes relationships between input variables and crop yield through a spatially explicit Bayesian model (McCann et al., 2006), represented in Fig. 2 and calibrated on historical data including precipitation, temperature, manure and fertilizer application, and crop yield in Llanada Alavesa. Although we recognize the importance of representing the diversity in the cropping systems, we considered its effect to be out of scope for this preliminary analysis and modeled only one crop, winter wheat, which amounts to $57 \%$ of total cereal production in the region and 54\% of the total area (MARM, 2011; MAGRAMA 2012).

Yield is estimated in the Bayesian model as a function of soil nitrogen availability, water availability, and temperature. Soil nitrogen availability is derived from the use of fertilizer and manure, which is restricted in those areas as regulated by law (BOPV, 2008).

Water availability depends on a combination of natural and management-induced conditions, of which the most important are: precipitation, irrigation, tillage and soil type. For simplicity, we focused on the period in which water availability has the highest impact on crop yield, corresponding to January to April in the case of winter wheat. This is the period that goes from tillering - the emergence of side shoots at leaf-stem junctions - to stem extension, in which most of the yield components are affected when water stress occurs.

The version of the model presented in this publication omits the effects of floods brought about by extreme precipitation, however it does account for the effect of excessive rainfall.

The model considers the average above ground temperature during the critical crop growth period, which corresponds to the grain filling stage for winter wheat in the Llanada Alavesa, occurring 
between May and July. During this period it is assumed that winter wheat yield decreases by $3 \%$ to $4 \%$ for each $1^{\circ} \mathrm{C}$ rise in mean temperature above $15^{\circ} \mathrm{C}$ (Wardlaw and Wrigley, 1994).

Available data show that over $99 \%$ of the manure used on these crops is distributed between cattle slurry, pig slurry and poultry litter; spatially explicit data were made available by the Basque Government to document the total quantity and relative proportion of each source in the area. In addition to the quantity of manure applied, chemical fertilizer and soil type also affect soil nitrogen availability through infiltration and leaching. Fig. 2 shows the Bayesian network diagram for the crop yield sub-model.



Fig. 2. Bayesian diagram for the winter wheat yield model.

\subsubsection{Climate regulation}

Agriculture can sequester carbon through changes in cultivation practices (e.g. reduced tillage) or by increasing soil carbon inputs (e.g. manure application) (Sanderman et al., 2009; Aguilera et al., 2013; Hillier et al., 2012). Agriculture is also an important source of emissions of $\mathrm{N}_{2} \mathrm{O}$ due to the use of fertilizer and manure. The emission of $\mathrm{N}_{2} \mathrm{O}$ currently is the single most important ozone-depleting emission and is expected to remain the largest throughout the $21^{\text {st }}$ century (Ravishankara et al., 2009). Among GHG, $\mathrm{N}_{2} \mathrm{O}$ 's contribution to climate forcing is second only to methane and is already much larger than that of all currently recognized ozone-depleting substances (Ravishankara et al., 2009). Furthermore, production of fertilizers is one of the most relevant sources of $\mathrm{CO}_{2}$ emissions from burning fossil fuel (Vermeulen et al., 2012).

We modeled the effect of management and site conditions on climate regulation as net warming potential, expressed as $\mathrm{CO}_{2}$ equivalent. This is due to:

1. Soil net carbon stock changes;

2. Direct soil $\mathrm{N}_{2} \mathrm{O}$ inputs;

3. Indirect emissions associated with the manufacturing of mineral fertilizers.

We estimated changes in soil carbon stock according to the IPCC Tier 1 approach for croplands (IPCC, 2006) and converted to annual estimates following Smith et al. (2007). This method is based on changes in soil organic carbon (SOC) stocks over a finite period of time, assuming that:

- Under specific climate and management conditions SOC stocks will tend towards equilibrium; 
- Changes in agricultural practices will affect SOC stocks, generating a transition period towards a new steady state;

- SOC stocks will change in a linear fashion during this transition.

Because annual crops such as winter wheat are harvested each year, it is reasonable to assume that no long-term sequestration of carbon in biomass takes place. Land management practices related to tillage and manure application are considered due to their effect on soil carbon sequestration by reducing soil disturbance and/or increasing carbon inputs. Our estimates of change in SOC stocks caused by changes in tillage practices are derived from Ogle et al. (2005) and take into consideration climatic factors (e.g. temperature).

The effect of manure application on soil carbon sequestration is modeled according to Smith et al. (1997) and considers the influence of manure availability, manure type, and the amount of manure rate applied.

We also took into account that a part of the modeled area is considered nitrate-vulnerable and subject to fertilizer use restrictions.

We modeled soil $\mathrm{N}_{2} \mathrm{O}$ emissions using an alternative Tier 1 IPCC-based approach (IPCC, 2006) that takes into account emissions from different nitrogen input sources, such as mineral fertilizer, manure, plant residues (assumed linearly dependent on yield) and soil organic matter. This alternative method, differently from the standard IPCC-based approach, is meant to estimate the potential effect of not only fertilization management (fertilization rate) but also site conditions (e.g. soil type) on soil $\mathrm{N}_{2} \mathrm{O}$ emissions. Therefore, site- and management-specific emission factors, meant to improve on the single-factor Tier 1 IPCC approach, have been developed after running an existing crop rotation model for GHG emissions $\left(\right.$ SIMS $_{\text {NIC }}$ model: Gallejones et al., 2014) using 50 years of local climatic data. This alternative set of emission factors was multiplied by the four types of nitrogen input sources considered. The effect of tillage on soil $\mathrm{N}_{2} \mathrm{O}$ is modeled indirectly through yield; we avoid representing the direct effect as the literature lacks consensus on both the expected magnitude and direction (e.g. Pinto et al., 2004).

Although we don't pretend to exhaustively cover the entire set of life cycle emissions, it has been demonstrated that energy consumption during fertilizer production has a prominent role in indirect GHG emissions (Brentrup et al., 2001). At the same time these emissions are relatively straightforward to estimate, being primarily linked to the type and the quantity of fertilizer applied. Indirect emissions from manufacturing of mineral fertilizers were obtained from the Ecoinvent database, which compiles emissions associated to the production of many chemical fertilizers applied in European agriculture (Nemecek and Kägi, 2007).

\subsubsection{Air quality}

Air pollution from $\mathrm{NH}_{3}$ is a major air quality concern at regional, national, and global levels. $\mathrm{NH}_{3}$ is a potent acidifier of ecosystems and a cause of respiratory problems.

We modeled $\mathrm{NH}_{3}$ emissions from livestock manure application as a function of the proportion of "readily available" nitrogen in manure (RAN) multiplied by an emission factor that represents the fraction of nitrogen volatilized to the atmosphere. RAN refers to the forms of nitrogen that are available for plant uptake (i.e. $\mathrm{NO}_{3}$ - and $\mathrm{NH}_{4}+$ ). The proportion of $\mathrm{RAN}$ that is volatilized to $\mathrm{NH}_{3}$ was calculated based on manure type, general weather conditions and mode of manure application, following the methods described for the MANNER model (Chambers et al., 1999).

\subsubsection{Water quality}

Water quality in this study is estimated by combining indicators of (1) nitrate leaching (expressed as average $\mathrm{NO}_{3}$ concentration in the leachate) and (2) phosphorus losses from the agricultural soil. Nitrate concentrations from leaching to ground and surface water threaten human and aquatic ecosystems in different ways. Nitrate-polluted aquifers may result in direct human health risks, 
whereas nutrient enrichment in aquatic ecosystems produces eutrophication, which is responsible for toxic algal blooms, water anoxia and habitat and biodiversity loss (Sutton et al., 2013).

Farmers apply commercial phosphorus-based fertilizers to supplement usually low quantities available in the soil. Dissolved phosphorus that is transported from farm fields to lakes, rivers, and streams can lead to excessive aquatic plant growth, resulting in eutrophication. Phosphorus can be a limiting factor for biomass production in freshwater ecosystems; even small amounts (i.e. $0.02 \mathrm{mg} / \mathrm{l}$ ) added to the system can produce significant increases in plant and algal growth (Sharpley et al., 2000).

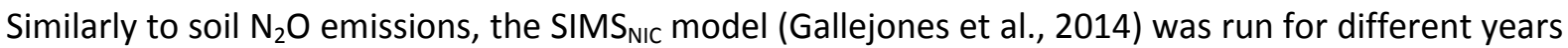
and soil types, producing specific estimates of $\mathrm{NO}_{3}$ leaching for different combinations of soil types and nitrate input rates.

We modeled phosphorus losses by re-implementing the approach of Davison et al. (2008) in Bayesian network form. Based on Davison et al. (2008), the model simulates risk of losses of elemental phosphorus to watercourses from soil (as particulate attached to the eroded soil and dissolved phosphorus from leaching) and applications of phosphorus in manure and fertilizer. Each of these sources is individually estimated in Davison et al. (2008) based on a water balance function derived for each soil-crop-climate combination. Losses of phosphorus from fertilizer and manure are scaled according to application rate. As in Davison et al. (2008) our model does not take into account the effect of tillage, because the parameterization of this factor, which requires unavailable field experiments, is out of the scope of this demonstrative implementation. However, the underestimation of runoff derived losses is assumed to be limited for this specific case study, given the flat morphology of the region.

\section{Results}

\subsection{Sensitivity analysis}

In the following we discuss the sensitivity analysis carried out on the Bayesian networks modules, a summary of which is included in Table 1 . The $\mathrm{NH}_{3}$ module, not included in Table 1, is a deterministic algorithm that is sensitive to the use of manure and, to a lesser degree, to precipitation. Results show that the quantity of manure applied and the soil type affect the output of all sub-models. Both variables were provided to the model as spatially explicit input data (i.e. raster maps containing an average yearly quantity of manure according to current practices and a soil type category per each cell) and used to establish baseline conditions.

Table 1. Output of sensitivity analysis for probabilistic model components.

\begin{tabular}{|c|c|c|c|}
\hline Module Output & Most influential input factors & $\begin{array}{c}\text { Coefficient of } \\
\text { variation }\end{array}$ & $\begin{array}{c}\text { Normalized rate of } \\
\text { influence }\end{array}$ \\
\hline \multirow{3}{*}{$\begin{array}{ll}\text { Carbon } & \text { Stock } \\
\text { Change } & \end{array}$} & Tillage Management Change & 0.38 & $60 \%$ \\
\hline & Manure Usage & 0.20 & $32 \%$ \\
\hline & Manure Type & 0.02 & $4 \%$ \\
\hline \multirow{4}{*}{$\begin{array}{l}\text { Nitrate } \\
\text { Leaching } \\
\text { Concentration }\end{array}$} & Soil Type & 0.23 & $59 \%$ \\
\hline & Manure Usage & 0.07 & $17 \%$ \\
\hline & Fertilizer Usage & 0.05 & $12 \%$ \\
\hline & Tillage & 0.04 & $11 \%$ \\
\hline \multirow{3}{*}{$\begin{array}{l}\text { Phosphorus } \\
\text { Loss }^{*}\end{array}$} & Manure Usage & 0.13 & $47 \%$ \\
\hline & Soil Type & 0.13 & $47 \%$ \\
\hline & Fertilizer Usage & 0.02 & $6.3 \%$ \\
\hline \multirow[t]{3}{*}{$\mathrm{N}_{2} \mathrm{O}$ Emissions } & Soil Type & 0.63 & $74 \%$ \\
\hline & Manure Usage & 0.21 & $22 \%$ \\
\hline & Water Availability & 0.02 & $2.1 \%$ \\
\hline
\end{tabular}




\begin{tabular}{|l|l|c|c|}
\hline \multirow{3}{*}{ Yield } & Manure Usage & 0.14 & $62 \%$ \\
\cline { 2 - 4 } & Precipitation & 0.03 & $16 \%$ \\
\cline { 2 - 4 } & Soil Type & 0.014 & $6 \%$ \\
\hline
\end{tabular}

Note. In the fourth column, $100 \%$ is the sum of the coefficient of variations of each input factor. * Tillage is not included in the Bayesian model for Phosphorous loss (see Section 2.2.4).

A first stage sensitivity analysis concludes that manure usage, precipitation and soil type are the inputs which explain most of the variation of the network's output node. The third column of Table 1 reports the coefficient of variation in output values due to changes in input values, i.e. the maximum variation in the expected probability of one state of an output node as a consequence of changing the state of the input node. For this assessment, a conditional confidence analysis (Frey and Patil, 2002) was performed, taking each input individually. For every state of the output node (i.e. yield) the variation of the marginal probability was computed over all the possible states of the input nodes.

A second stage of analysis was performed to determine more succinctly how the three most influential inputs affect the variation of the output node over the entire variation attributable to the inputs. The rate of influence in column 4 of Table 1 expresses the percentage of the overall variation that can be attributed to each input $(100 \%$ is the sum of the coefficient of variation of all the input factors). In the yield example described, the ranking shows that manure usage is the most influential input, with a $62 \%$ normalized rate of influence.

\subsection{Aggregated trade-offs}

The outputs of all sub-models consist of spatially explicit raster maps. In order to highlight ES tradeoffs for the entire region, we have summarized the spatial outputs using mean regional values. The model was run over alternative "extreme" scenarios, meant to capture effects of both environmental conditions (precipitation and temperature) and management choices (application of manure and practice of tillage). We selected two cases for each of three driving variables (factors in Table 1), resulting in a total of eight scenarios.

1. Climatic factors. We based our scenarios on available climatic records describing actual conditions during the 50 years from 1958 to 2008, with daily measurement of rainfall and average temperature recorded by weather stations managed by the Basque government. Estimates of evapotranspiration were computed using the SIMS $_{\text {NIC }}$ model (Gallejones et al., 2014), a water balance model broadly based on the algorithms described in Allen et al. (1998). The same model was used to compute water filled pore space, a measure of soil moisture. Evapotranspiration was computed using the Hargreaves-Samani equation (Hargreaves and Samani, 1985) calibrated using the Penman-Monteith FAO 56 evapotranspiration equation for the Basque Country (Landeras et al., 2009).

In order to test the effect of precipitation and temperature we ran the integrated model using input data from two historical periods (1997 and 2007) in which widely different crop yields were recorded. Year 1997 was an adverse year for winter wheat because the average rainfall during the critical January-April period was relatively low (about $45 \mathrm{~mm}$, with respect to a 69 $\mathrm{mm}$ 50-years average) and the temperature during the critical May-July period was relatively high (an average of $\sim 16.5^{\circ} \mathrm{C}$, with respect to $15.9^{\circ} \mathrm{C} 50$-years average). In contrast, 2007 was a favorable year, with average monthly precipitation of $90 \mathrm{~mm}$ and an average daily temperature of $15.5^{\circ} \mathrm{C}$ in the correspondent periods.

2. Manure usage. In this scenario we looked at the implications of reducing the use of manure in the area by setting manure application at the highest and lowest levels encoded in the Bayesian network. The highest level represents the interval 30-90 $\mathrm{Kg} \mathrm{N} / \mathrm{Ha}$. The lowest level represents the interval $0-10 \mathrm{Kg} \mathrm{N} / \mathrm{Ha}$. In order to isolate the effect of manure application, this scenario does 
not modify the amount of chemical fertilizer, which is kept at the baseline level of $\sim 170 \mathrm{Kg} \mathrm{N} / \mathrm{ha}$. This is representative of actual conditions, as usage of organic and chemical fertilizers is customarily decided independently in the case study area (BOPV, 2008).

3. Tillage practices. We tested the implications of a scenario compatible with criteria of conservation agriculture, which emphasizes reduction or elimination of mechanical soil disturbances (Verhulst et al., 2010; Balmford et al., 2012). Currently 99\% of the agricultural land is subject to tillage. This baseline was compared with a scenario in which the entire case study area is shifted from conventional tillage to absence of tillage.

The factorial schema used to define the scenarios is summarised in Table 2. The implications for ES in each scenario are discussed in the following by comparing output maps in their aggregated form. A comprehensive summary of these results is presented in Fig. 3.

Table 2. Factors used to develop the testing scenarios

\begin{tabular}{|c|c|c|c|c|c|}
\hline \multicolumn{4}{|c|}{ Factor 1} & Factor 2 & Factor 3 \\
\hline Year & $\begin{array}{c}\text { Environmental } \\
\text { conditions }\end{array}$ & $\begin{array}{c}\text { Average monthly } \\
\text { temperature } \\
\text { during critical } \\
\text { period }\end{array}$ & $\begin{array}{c}\text { Average monthly } \\
\text { precipitation } \\
\text { during critical } \\
\text { period }\end{array}$ & Manure use & Tillage practices \\
\hline 1997 & Suboptimal & $16.5^{\circ} \mathrm{C}$ & $45 \mathrm{~mm}$ & High $(30-90 \mathrm{Kg}-\mathrm{N} / \mathrm{Ha})$ & Conventional \\
\hline 2007 & Favorable & $15.5^{\circ} \mathrm{C}$ & $90 \mathrm{~mm}$ & Low $(0-10 \mathrm{Kg}-\mathrm{N} / \mathrm{Ha})$ & No-tillage \\
\hline
\end{tabular}

Note. Eight possible "extreme" scenarios result from the combination of two cases for each factor.

\subsubsection{Climatic factors}

The crop yield module was calibrated to the 50 years climatic data series and yield statistics available from agricultural surveys for the entire region. Empirical data were used for manure and chemical fertilizer application. Model estimates of average winter wheat yields matched recorded yields of climatically favorable years within $2.5 \%$ while they consistently overestimate yields of adverse years (+15\% on average).

Assuming the presence of tillage and high usage of manure (between 30 and $90 \mathrm{Kg} \mathrm{N} / \mathrm{Ha}$ ), the results suggest that favorable rain and temperature conditions can increase the yield up to $10 \%$ with respect to less favorable ones. This translates into yield gains (or losses) of half a ton per hectare from one year to the next. This estimated effect, isolated from other human related variables, is not very significant but it is consistent with the fact that winter wheat is a drought-resistant crop, since it is typically rain-fed and the two reference years are not very divergent with respect to temperature. Furthermore, precipitation also promotes important reductions of the effects on ammonia emissions and nitrate leaching. Assuming that manure is applied from March to April, the increased probability of rainfall after application determines an estimated reduction of $3 \mathrm{Kg} \mathrm{NH}_{3}-\mathrm{N} / \mathrm{Ha}(60 \%)$. Nitrate leaching concentration is reduced by $25 \%(2.92 \mathrm{mg} / \mathrm{l})$ because of greater uptake of nutrients by the plant and of the increased dilution effect. On the contrary, increased precipitation barely increases $\mathrm{N}_{2} \mathrm{O}(0.45 \%)$ emissions.

With minimum usage of manure $(0-10 \mathrm{Kg} \mathrm{N} / \mathrm{Ha})$ the effects on yield, ammonia and nitrate leaching remain similar in relative terms, but change in absolute value by $+225 \mathrm{Kg} / \mathrm{Ha},-0.7 \mathrm{Kg} \mathrm{NH}_{3}-\mathrm{N} / \mathrm{Ha}$, and $-2.57 \mathrm{mg} / \mathrm{l}$ respectively. With low manure application all these variations decrease in absolute terms. 
$\square$ Impact of favorable rainfall and temperature

Impact of reducing manure usage

Impact of passing to zero tillage



$-50 \%$

$-30 \%$

$-3 \mathrm{Kg} /(\mathrm{ha} * \mathrm{y})$

NH3 Emissions $-1.7 \mathrm{Kg} /\left(\mathrm{ha}^{*} \mathrm{y}\right)$

Carbon Stock

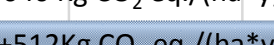

$-2.92 \mathrm{mg} / \mathrm{l}$

NO3 Leaching $-1.38 \mathrm{mg} / \mathrm{l}$

$-0.7 \mathrm{mg} / \mathrm{l}$

$+10 \mathrm{Kg} \mathrm{CO}{ }_{2}$ eq./(ha*y)

$-480 \mathrm{Kg} \mathrm{CO}_{2}$ eq./(ha*y)

$+427 \mathrm{Kg} /(\mathrm{ha} * \mathrm{y})$

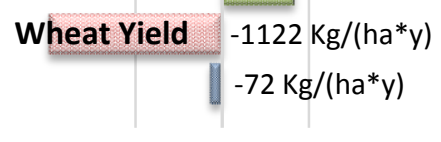

Fig. 3. Relative (projected on the X-axis) and absolute variations of the average parameters' values for the entire region. The green bars capture the implications of varying from suboptimal to favorable temperature and rainfall while maintaining conventional tillage and high manure usage. The red bars show the effect of reducing manure usage with favorable environmental conditions and conventional tillage. The blue bars show the effect of passing from conventional tillage to no-tillage with favorable environmental conditions and high manure usage. Certain parameters are not sensitive to changes in environmental conditions and/or tillage practices, therefore the bar is absent. 


\subsubsection{Manure usage}

Assuming the presence of tillage with favorable environmental conditions, a significant reduction of the application of manure can reduce yield up to 20\% (approximately 1.1 ton per hectare). This corresponds to high opportunity cost for any policy that further reduces nitrate application. In fact, under the same scenario, $\mathrm{NO}_{3}$ is reduced by about $12 \%$ (approximately $1.4 \mathrm{mg} / \mathrm{l}$ ) meaning that every $\mathrm{mg} / \mathrm{l}$ of $\mathrm{NO}_{3}$ reduction can cost about $800 \mathrm{Kg} / \mathrm{Ha}$ of yield. However, a reduction in manure application also cuts phosphorus losses by $23 \%$ and pollution due to ammonia emissions $(85 \%)$, corresponding to reductions of $\sim 0.189$ and $1.7 \mathrm{Kg} / \mathrm{Ha}$ per year respectively. Conversely, the effect on GHG emission can be seen as mixed: the loss of carbon stock can outweigh the decrease in nitrous oxide. While carbon stock decreases by $640 \mathrm{Kg} \mathrm{CO}_{2}$-equivalent per hectare, $\mathrm{N}_{2} \mathrm{O}$ emissions decrease of a total of $480 \mathrm{Kg} \mathrm{CO}_{2}$-equivalent per hectare. Here it should be noted that whereas certain types of mitigation activities (e.g. $\mathrm{N}_{2} \mathrm{O}$ reduction from decreased fertilization) are effectively permanent since the emissions, once avoided, cannot be re-emitted, some activities that affect the carbon stock can be temporary and reversible. Moreover, loss of carbon stock can directly affect supporting ES as soil formation and nutrient cycling.

With suboptimal environmental conditions the effect of decreasing manure on yield is tempered in absolute terms $(-900 \mathrm{Kg} / \mathrm{Ha})$, because the maximum potential yield decreases as well. For the same reason the impact of decreasing manure on nitrate leaching concentration intensifies remarkably (i.e. the leach decreases by $4 \mathrm{mg} / \mathrm{l}$ ) due to the absence of the dilution effect and a reduced uptake of nutrients by the plants.

\subsubsection{Tillage practice}

Assuming high usage of manure (between 30 and $90 \mathrm{Kg} \mathrm{N} / \mathrm{Ha}$ ) and favorable environmental conditions, the shift from a conventional tillage regime, as in current practice, to absence of tillage results in a significant increase in carbon stock sequestered in the ground. The increase is equal to approximately $512 \mathrm{Kg} / \mathrm{Ha}(+67 \%)$. This can be achieved with limited effect on yield: the model estimates a marginal change of about $1.3 \%(72 \mathrm{Kg} / \mathrm{Ha})$. This means that a net increase of $100 \mathrm{CO}_{2}$ equivalent per hectare of carbon stock costs about $15 \mathrm{Kg} / \mathrm{Ha}$ of yield. This can be explained by considering that the light soil texture conditions are favorable to promoting the necessary soil water capacity, which in conjunction with abundant precipitation and appropriate temperatures results in high yields. Importantly, interruption of tillage is also associated with a significant reduction of nitrate leaching concentration, quantified in about $0.7 \mathrm{mg} / \mathrm{l}(6 \%)$. Alternatively to the above described assumptions, with suboptimal environmental conditions the impact on yield loss is mitigated.

As shown in Fig. 3 the shift of tillage regime does not affect phosphorus losses and $\mathrm{N}_{2} \mathrm{O}$ emissions. This is related to the simplified models' architecture described in Section 2, which avoids key complexities that are not completely resolved according to the literature (e.g. Pinto et al., 2004; Davison et al., 2008).

\subsection{Spatially explicit output}

The results summarized in the previous section derive from the aggregation of output raster maps. A number of maps have been produced considering six output variables (i.e. winter wheat yield, carbon stock change, nitrate leaching concentration, phosphorus loss, nitrous oxide, and ammonia) and the correspondent uncertainties (e.g. Fig. 4b) in eight combinations of scenarios. In this section we show a representative selection of map outputs generated by running the winter wheat yield and the nitrous oxide modules.

The winter wheat yield module is a spatially explicit, Bayesian probabilistic production function, in which all map cells contain a distribution of values. Fig. 4a shows the mean value of the distribution in each point, while Fig. $4 \mathrm{~b}$ shows the correspondent dispersion, computed as coefficient of 
variation. Such output quantifies part of the uncertainty inherent in the data and model structure that generates them. This visual representation makes uncertainties in the results explicit to the user, a valuable insight for decision-making. Fig. $4 \mathrm{~b}$ shows that uncertainty is higher where the yield estimates are lower and that, in general, the level of uncertainty of this output is relatively low. Fig. $4 \mathrm{a}$ and Fig. 4c capture the two extreme scenarios concerning yield production. Fig. 4a represents the best scenario where the yield potential is supported by favorable environmental conditions, tillage and high usage of manure. On the other side Fig. $4 \mathrm{c}$ represents the worst case scenario for yield production, where environmental conditions are suboptimal, tillage is not practiced and the use of manure is limited. The simulations show a generalized yield decrease of approximately 1,350 $\mathrm{Kg} /($ ha* year).

The $\mathrm{N}_{2} \mathrm{O}$ module outputs are shown in Fig. 5a, 5b and 5c. Again we compare two extremes given by maximum usage of manure and good environmental conditions (Fig. 5a), and minimum manure usage and suboptimal environmental conditions (Fig. 5b). The simulations show a generalized emissions decrease of approximately 400 to $500 \mathrm{Kg} \mathrm{CO}_{2}$ equivalent/(ha*year). More precisely, in this case we show a map of the exact differentials (Fig. 5c). For example, a significant area in the northeast of the region decreases emission up to $675 \mathrm{Kg} \mathrm{CO}_{2}$ equivalent/(ha*year) and this area, as shown in Fig. 4, is not the most productive in absolute terms.

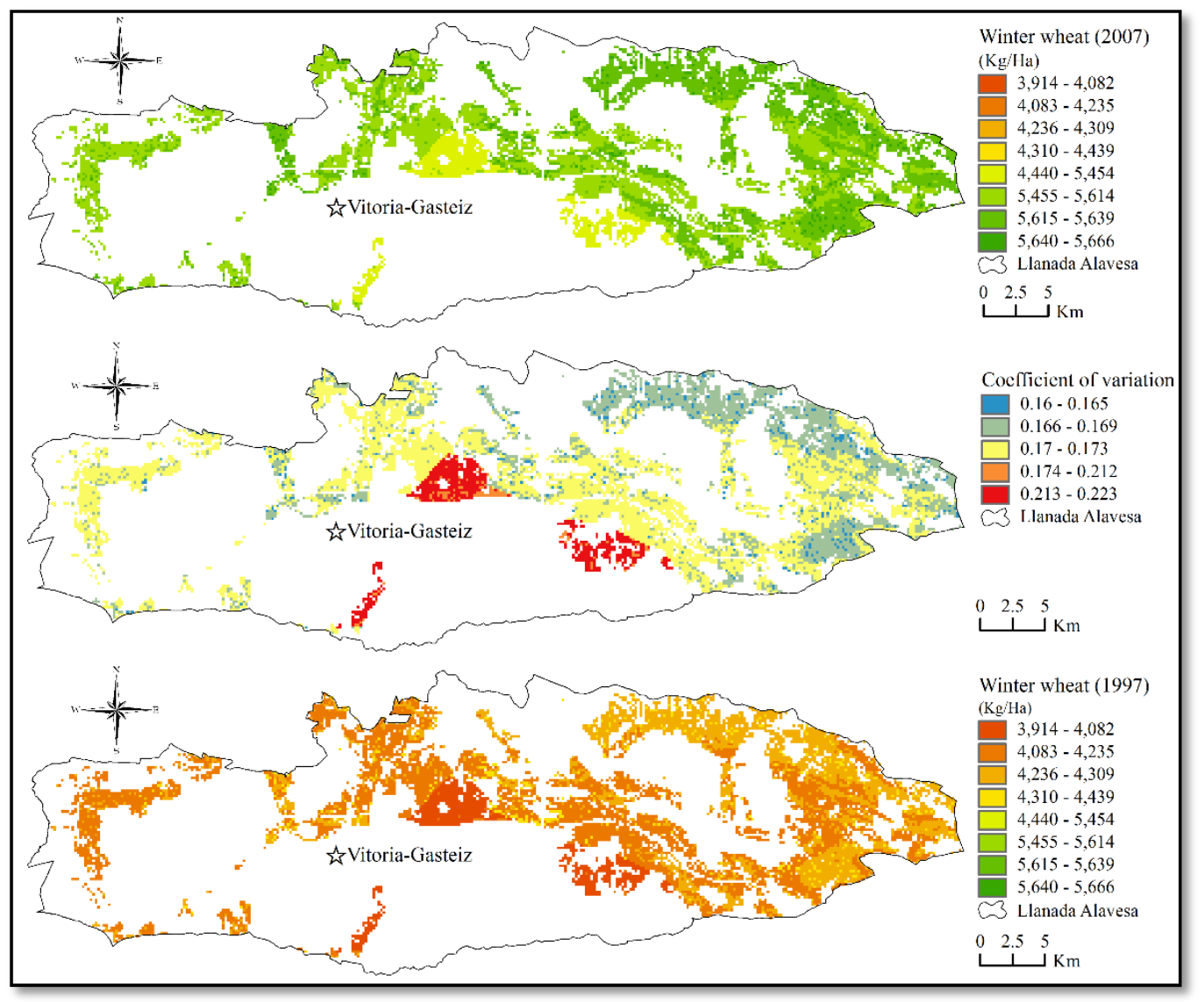

Fig. 4. a. Yield estimates for winter wheat with tillage and maximized manure usage with favorable environmental conditions (year 2007). b. Uncertainty (coefficient of variation) associated with the estimates of 4a. c. Yield estimates for winter wheat without tillage and minimized manure usage with suboptimal environmental conditions (year 1997). 




Fig. 5. a. $\mathrm{N}_{2} \mathrm{O}$ and indirect emissions estimates with tillage, maximized manure usage and favorable environmental conditions. b. $\mathrm{N}_{2} \mathrm{O}$ and indirect emissions estimates without tillage and with minimized manure usage and suboptimal environmental conditions. c. Absolute variation between $5 \mathrm{a}$ and $5 \mathrm{~b}$ (foregone emissions).

By comparing the outputs of the two modules it is possible to compute the ratio among differentials of yield production and $\mathrm{N}_{2} \mathrm{O}$ emissions for each pixel of the simulated landscape. The simulations of extreme scenarios can thus lead us to an approximate indicator of trade-off magnitude, expressed as $\mathrm{Kg}$ of foregone winter wheat yield production for every $\mathrm{Kg}$ of reduction in $\mathrm{CO}_{2}$ equivalents due to nitrous oxide and indirect emissions. Results suggest that in Llanada Alavesa a change to more conservative agricultural management practices, and in particular a limited use of manure, combined with dryer years - which can be understood as a proxy of climate change - can lead to losses around the order of 2 to $4.5 \mathrm{Kg}$ per hectare per year of winter wheat yield for each $\mathrm{Kg}$ of avoided $\mathrm{CO}_{2}$ emissions from nitrous oxide. Further analyses of similar nature could be produced for the remaining $\mathrm{ES}$ as described in the previous section.

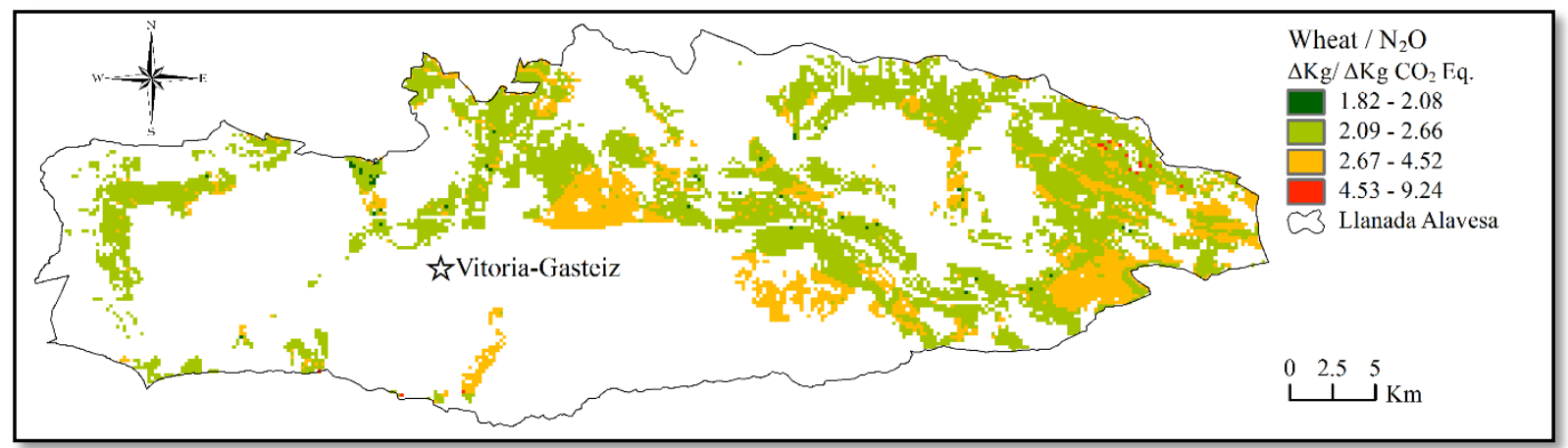

Fig. 6. Ratio among differentials of yield production and $\mathrm{CO}_{2}$ emissions per hectare per year due to limitation of manure usage and suboptimal environmental conditions. 


\section{Discussion and Conclusion}

For sustainable management of food production systems, it is necessary to analyse the ecologic and agronomic elements, the complex interdependencies between natural and anthropogenic factors and the trade-offs in ES flows. The modeling framework developed in this study is a generalized approach to this challenge. The spatially explicit model is applied to a case study of the agricultural landscape of Llanada Alavesa located in Basque Country, Northern Spain. Our analysis demonstrates the capability of the model to successfully carry out quantitative assessment of the synergies and trade-offs between various ES as a consequence of climatic conditions and management practices.

We used a novel semantically-driven simulation platform that is able to integrate models of different scale and nature, addressing some main challenges of in integrated modeling (Villa 2007; Villa 2009) such as modularity and collaborative model development, structural variability (the capacity to assemble models using a variety of sub-models according to their appropriateness), structural validation (internal model consistency) and synchronization of models (Moore and Tindall, 2005; David et al. 2013).

The application described in this article demonstrates the capability to automatically assemble and optimize the structure of ES models based on an independently extensible library of modular components, driven by context-specific data and machine-processed ES knowledge, avoiding the pitfalls of the common "one model fits all" paradigm. The assembling process employs a multicriteria algorithm considering suitability of data quality and fit to the context. The algorithm can be customized to specific needs by modelers (see Villa et al. 2014). The integrated model structure is made explicit to the modeler at run time as a provenance diagram (Simmhan et al., 2005) describing all the data and models in use along with the rationale of their inclusion.

These models and results substantiate an attempt to provide a more holistic approach to the prediction and management of agricultural systems. Aggregated results for six output variables (winter wheat yield, carbon stock change, nitrate leaching, phosphorus loss, nitrous oxide, and ammonia) are discussed with reference to different conditions of climate, manure application and tillage.

The main outputs indicate:

1. The cost of reducing ammonia emissions, nitrate leaching concentration and phosphorus losses, through a timely and measured manure application to the field, in terms of significant potential yield reduction.

2. The possibility of increasing the rate of carbon sequestration in the soil by moving from a conventional tillage practice to limited tillage. Our results suggest that this change does not translate into significant reductions on yield, at least in the case of winter wheat.

3. An additional benefit of non-tillage farming, linked to significant reductions of nitrate leaching concentration.

These results should be intended as a proof of concept aimed to illustrate the added value that the adoption of a modular and complexity-aware perspective can contribute to the understanding of agricultural systems.

The challenges posed by global change call for a more comprehensive view of the issues related to agricultural production, shifting focus from mere yield maximisation to a paradigm more broadly oriented to sustainability. In this light, urgent issues related to food security at the global level should be tempered with the awareness of the dependence on, and the impacts of, agricultural practices on all other ES.

In accordance with Swinton et al. (2007), who emphasized the necessity to develop cost-effective ways to meet this challenge using relatively less costly data, we showed a spatially explicit and scalable modeling framework that is able to work with a relatively limited amount of data, generally 
accessible in the public domain. Given the modular nature of the modeling infrastructure chosen, this approach enables the integration of more analytic modules and data sets to undertake detailed spatially explicit studies of ES under different management practices and agricultural landscapes.

While this work may offer some insights in this direction, its limitations and simplifications must be noted for the benefit of future investigations. Among these:

1. The modules used in this implementation are simple probabilistic models that neglect some relevant complexities and feedbacks. For example we are currently incorporating a processbased water balance model to better capture the dynamics of runoff and soil erosion.

2. The choice of ES is limited. Specifically, we did not account for crucial dimensions of agricultural systems such as water flows, pollination, organic matter and biodiversity.

3. The analysis is limited to provision of services and does not take into account the demand side of the modeled ES (e.g. food consumers);

4. Many more scenarios are of interest beyond those that we described. Although the model allows for it, we did not explore key variables such as the usage of chemical fertilizer;

5. We did not perform a dynamic analysis; instead, we looked at two bounded periods in a static way, only considering aggregated values for key indicators;

6. We only considered one crop without rotation dynamics.

In particular, we recognize the need to address dynamic aspects of agricultural systems to understand the temporal implications of policy options like the introduction of incentives through Payment for Ecosystem Services (PES) (FAO, 2007) as well as the farmers' response to them. For this reason we envisage a development of the models that includes agent-based components, in the line of Balbi et al. (2013), supported by correspondent extensions of the semantic meta-modeling framework.

Some of the limitations mentioned above will be addressed by employing additional modules and data sources. Our ultimate goal is to develop this tool into a collective effort where different data and models from different modellers can coexist and be assembled interchangeably depending on the appropriateness to the context of application.

\section{Acknowledgements}

This research was initially conceived during the first edition of the BC3 International Spring University on Ecosystem Services Modeling (http://www.bc3research.org/springuniversity/). The authors would like to acknowledge the other instructors and members of the agricultural group not participating in this paper. The ARIES/Thinklab technology was developed by co-author Villa with support from the US National Science Foundation (grant 9982938), and the ASSETS project funded by ESPA/NERC (grant NE-J002267-1) among others. Funding from the Spanish Ministry of Economy and Competitiveness through the project CAUSE under the 2012 National Plan for non-oriented research is also gratefully acknowledged. Finally, the authors wish to thank the anonymous reviewers and the editors. 


\section{References}

Aguilera, E., Lassaletta, L., Gattinger, A., Gimeno, B. S., 2013. Managing soil carbon for climate change mitigation and adaptation in Mediterranean cropping systems: A meta-analysis. Agr. Ecosyst Environ. 168, 25-36.

Allen, R., Pereira, L., Raes, D., Smith, M., 1998. Crop evapotranspiration-Guidelines for computing crop water requirements-FAO irrigation and drainage paper 56. FAO, Rome.

Arriagada, R., Perrings, C., 2011. Paying for International Environmental Public Goods. Ambio 40, 798-806.

Athanasiadis, I.N., Janssen, S., Huber, D., Rizzoli, A.E., van Ittersum, M., 2007. Semantic Modeling in Farming Systems Research-The Case of the Agricultural Management Definition Module, in: Information Technologies in Environmental Engineering. Springer, 417-432.

Bagstad, K.J., Johnson, G.W., Voigt, B., Villa, F., 2013a. Spatial dynamics of ecosystem service flows: A comprehensive approach to quantifying actual services. Ecosyst. Serv. 4, 117-125.

Bagstad, K.J., Semmens, D.J., Waage, S., Winthrop, R., 2013b. A comparative assessment of decisionsupport tools for ecosystem services quantification and valuation. Ecosyst. Serv. 5, 27-39.

Balbi, S., Bhandari, S., Gain, A. K., Giupponi, C., 2013. Multi-agent agro-economic simulation of irrigation water demand with climate services for climate change adaptation. Ita. J. Agron. $8(3)$, e23.

Balmford, A., Green, R., Phalan, B., 2012. What conservationists need to know about farming. Proc. R. Soc. B Biol. Sci. 279, 2714-2724.

Barraquand, F., Martinet, V., 2011. Biological conservation in dynamic agricultural landscapes: Effectiveness of public policies and trade-offs with agricultural production. Ecol. Econ. 70, 910-920.

Belcher, K.W., Boehm, M.M., Fulton, M.E., 2004. Agroecosystem sustainability: a system simulation model approach. Agric. Syst. 79, 225-241.

Bennett, E.M., Peterson, G.D., Gordon, L.J., 2009. Understanding relationships among multiple ecosystem services. Ecol. Lett. 12, 1394-1404.

BOPV, 2008. ORDEN de 15 de octubre de 2008, de la Consejera de Medio Ambiente y Ordenación del Territorio y del Consejero de Agricultura, Pesca y Alimentación, por la que se aprueba el plan de actuación sobre las zonas declaradas vulnerables a la contaminación de las aguas por los nitratos procedentes de la actividad agraria. Boletín oficial del País Vasco.

Bommarco, R., Kleijn, D., Potts, S.G., 2013. Ecological intensification: harnessing ecosystem services for food security. Trends Ecol. Evol. 28, 230-238.

Boyd, J., Banzhaf, S., 2007. What are ecosystem services? The need for standardized environmental accounting units. Ecol. Econ. 63, 616-626.

Braat, L.C., De Groot, R., 2012. The ecosystem services agenda: bridging the worlds of natural science and economics, conservation and development, and public and private policy. Ecosyst. Serv. 1, 4-15.

Brentrup, F., Küsters, J., Kuhlmann, H., Lammel, J., 2001. Application of the Life Cycle Assessment methodology to agricultural production: an example of sugar beet production with different forms of nitrogen fertilisers. Eur. J. Agron. 14(3), 221-233.

Bruinsma, J., 2009. The resource outlook to 2050, in: Expert Meeting on "How to Feed the World in 2050.

Brown, L.R., 2012. Full Planet, Empty Plates: The New Geopolitics of Food Scarcity, W.W. Norton \& Company, New York, USA.

Burkett, V.R., Wilcox, D.A., Stottlemyer, R., Barrow, W., Fagre, D., Baron, J., ..., Doyle, T., 2005. Nonlinear dynamics in ecosystem response to climatic change: Case studies and policy implications. Ecol. Complex. 2, 357-394. 
Chambers, B.J., Lord, E.I., Nicholson, F.A., Smith, K.A., 1999. Predicting nitrogen availability and losses following application of organic manures to arable land: MANNER. Soil Use Manage. 15, 137-143.

Coase, R.H., 1960. The problem of social cost. J. Law Econ. 3, 1-44.

Daily, G.C., Polasky, S., Goldstein, J., Kareiva, P.M., Mooney, H. a, Pejchar, L., ..., Shallenberger, R., 2009. Ecosystem services in decision making: time to deliver. Front. Ecol. Environ. 7, 21-28.

David, O., Ascough, I.J.C., Lloyd, W., Green, T.R., Rojas, K.W., 2013. A software engineering perspective on environmental modeling framework design: The Object Modeling System. Environ. Model. Softw. 39, 201-213.

Davison, P.S., Withers, P.J.A., Lord, E.I., Betson, M.J., Strömqvist, J., 2008. PSYCHIC - A process-based model of phosphorus and sediment mobilisation and delivery within agricultural catchments. Part 1: Model description and parameterisation. J. Hydrol. 350, 290-302.

De Groot, R., 2002. A typology for the classification, description and valuation of ecosystem functions, goods and services. Ecol. Econ. 41, 393-408.

Deininger, K.W., Byerlee, D., 2011. Rising global interest in farmland: can it yield sustainable and equitable benefits? World Bank Publications.

Dominati, E., Patterson, M., Mackay, A., 2010. A framework for classifying and quantifying the natural capital and ecosystem services of soils, Ecol. Econ. 69(9), 1858-1868.

Elmqvist, T., Tuvendal, M., Krshnaswamy, J., Hylander, K., 2011. Managing trade-offs in ecosystems services. Ecosystem Services Economies, Working Paper 4. UNDP, Division of Environ. Policy Implementation.

FAO, 2007. State of Food and Agriculture Report 2007: Paying Farmers for the Environmental Services. Food and Agriculture Organization of the United Nations, Rome, Food and Agriculture Organization of the United Nations, Rome, Italy.

Fisher, B., Turner, K., Zylstra, M., Brouwer, R., De Groot, R., Farber, S., ..., Harlow, J., 2008. Ecosystem services and economic theory: integration for policy-relevant research. Ecological Applications 18, 2050-2067.

Fisher, B., Turner, R.K., Burgess, N.D., Swetnam, R.D., Green, J., Green, R.E., ..., Balmford, A., 2011. Measuring, modeling and mapping ecosystem services in the Eastern Arc Mountains of Tanzania. Prog. Phys. Geogr. 35, 595-611.

Foley, J.A., Defries, R., Asner, G.P., Barford, C., Bonan, G., Carpenter, S.R., ..., Snyder, P.K., 2005. Global consequences of land use. Science 309, 570-4.

Frey, C.H., Patil, S.R., 2002. Identification and review of sensitivity analysis methods. Risk analysis 22(3), 553-578.

Gallejones, P., Aizpurua, A., Ortuzar-Iragorri, A., del Prado, A., 2014. Development of a new model for the simulation of $\mathrm{N} 2 \mathrm{O}$ emissions: A case-study on wheat cropping systems under humid Mediterranean climate. Mitig. Adapt. Strateg. Glob. Chang. , 1-24.

Galloway, J., Dentener, F., Capone, D., Boyer, E., Howarth, R., Seitzinger, S., Asner, G., Cleveland, C., Green, P., Holland, E., Karl, D., Michaels, A., Porter, J., Townsend, A. \& Vöosmarty, C., 2004. Nitrogen Cycles: Past, Present, and Future Biogeochemistry, Kluwer Academic Publishers, 70, 153-226.

Glendining, M.J., Dailey, A.G., Williams, A.G., Evert, F. V., Goulding, K.W.T., Whitmore, A.P., 2009. Is it possible to increase the sustainability of arable and ruminant agriculture by reducing inputs? Agric. Syst. 99, 117-125.

Godfray, H.C.J., Beddington, J.R., Crute, I.R., Haddad, L., Lawrence, D., Muir, J.F., Pretty, J., Robinson, S., Thomas, S.M., Toulmin, C., 2010. Food security: the challenge of feeding 9 billion people. Science 327, 812-818.

Gordon, L.J., Finlayson, C.M., Falkenmark, M., 2010. Managing water in agriculture for food production and other ecosystem services. Agric. Water Manag. 97, 512-519.

Haines-Young, R., Potschin, M., 2010. The links between biodiversity, ecosystem services and human well-being. Ecosystem Ecology: a new synthesis 110-139. 
Hargreaves, G. H., Samani, Z. A., 1985. Reference crop evapotranspiration from temperature. Appl. Eng. Agric. 1, 2, 96-99.

Helliwell, D.R., 1969. Valuation of wildlife resources. Reg. Stud. 3, 41-47.

Hillier, J., Brentrup, F., Wattenbach, M., Walter, C., Garcia-Suarez, T., Mila-i-Canals, L., Smith, P., 2012. Which cropland greenhouse gas mitigation options give the greatest benefits in different world regions? Climate and soil-specific predictions from integrated empirical models. Glob. Chang. Biol. 18, 1880-1894.

Holzworth, D.P., Huth, N.I., deVoil, P.G., Zurcher, E.J., Herrmann, N.I., McLean, G., ..., Keating, B.A., 2014. APSIM-evolution towards a new generation of agricultural systems simulation. Environ. Mod. Soft., in Press.

IPCC, 2006. IPCC Guidelines for National Greenhouse Gas Inventories, Prepared by the National Greenhouse Gas Inventories Programme, Eggleston, H.S., Buendia, L., Miwa K., Ngara, T., Tanabe, K. (Eds.). IGES, Japan.

IPCC, 2007. Climate change 2007-the physical science basis: Working group I contribution to the fourth assessment report of the IPCC. Cambridge University Press.

Johnston, R.J., Russell, M., 2011. An operational structure for clarity in ecosystem service values. Ecol. Econ. 70, 2243-2249.

Jones, J.W., Hoogenboom, G., Porter, C.H., Boote, K.J., Batchelor, W. D., Hunt, L.A, ..., Ritchie, J.T., 2003. The DSSAT cropping system model. Eur. J. Agron., 18(3), 235-265.

Kleijn, D., Baquero, R.A., Clough, Y., Diaz, M., De Esteban, J., Fernandez, F., ..., Yela, J.L., 2006. Mixed biodiversity benefits of agri-environment schemes in five European countries. Ecol. Lett. 9, 243-254.

Knisel, W.G., 1980. CREAMS: a field scale model for Chemicals, Runoff, and Erosion from Agricultural Management Systems [USA] United States. Dept. of Agriculture. Conservation research report, Dept. of Agriculture, Science and Education Administration.

Koch, E.W., Barbier, E.B., Silliman, B.R., Reed, D.J., Perillo, G.M.E., Hacker, S.D., ..., Wolanski, E., 2009. Non-linearity in ecosystem services: temporal and spatial variability in coastal protection. Front. Ecol. Environ. 7(1), 29-37.

Koschke, L., Fürst, C., Lorenz, M., Witt, A., Frank, S., Makeschin, F., 2013. The integration of crop rotation and tillage practices in the assessment of ecosystem services provision at the regional scale. Ecol. Indic. 32, 157-171.

Krutilla, J.V., 1967. Conservation reconsidered. Am. Econ. Rev. 57, 777-786.

Landeras, G., Ortiz-Barredo, A., López, J., 2009. Forecasting Weekly Evapotranspiration with ARIMA and Artificial Neural Network Models. J. Irrig. Drain. Eng. 135, 323-334.

Layke, C., 2009. Measuring nature's benefits: a preliminary roadmap for improving ecosystem service indicators. World Resource Institute, Washington DC.

Leonard, R.A., Knisel, W.G., 1987. GLEAMS: Groundwater Loading Effects of Agricultural Management Systems. Trans. ASAE 305, 1403-1418.

Lorenz, M., Fürst, C., Thiel, E., 2013. A methodological approach for deriving regional crop rotations as basis for the assessment of the impact of agricultural strategies using soil erosion as example. J. Environ. Manage. 127, S37-S47.

Lotze-Campen, H., Müller, C., Bondeau, A., Rost, S., Popp, A., Lucht, W., 2008. Global food demand, productivity growth, and the scarcity of land and water resources: a spatially explicit mathematical programming approach. Agric. Econ. 39, 325-338.

Madin, J.S., Bowers, S., Schildhauer, M.P., Jones, M.B., 2008. Advancing ecological research with ontologies. Trends Ecol. Evol. 23, 159-168.

Maes, J., Egoh, B., Willemen, L., Liquete, C., Vihervaara, P., Schägner, J. P., ..., Bidoglioa, G., 2012. Mapping ecosystem services for policy support and decision making in the European Union. Ecosyst. Serv. 1(1), 31-39. 
Magliocca, N.R., Brown, D.G., Ellis, E.C., 2013. Exploring Agricultural Livelihood Transitions with an Agent-Based Virtual Laboratory: Global Forces to Local Decision-Making. PLoS One 8, e73241.

MAGRAMA, Ministerio de Agricultura, Alimentación y Medio Ambiente, 2012. Superficies y producciones anuales de cultivo de acuerdo con el Reglamento (CE) 543 / 2009.

MARM, Ministerio de Medio Ambiente y Medio Rural y Marino, 2011. Caracterización de las Comarcas Agrarias de España, Tomo 1: Comunidades Autónomas.

McCann, R.K., Marcot, B.G., Ellis, R., 2006. Bayesian belief networks: applications in ecology and natural resource management. Can. J. For. Res. 36, 3053-3062.

Metherell, A.K., Harding, L.A., Cole, C. V, Parton, W.J., 1993. CENTURY: soil organic matter model. Technical Document, Agroecosystems version 4.0. Great Plains Systems Research Unit, US Department of Agriculture, Agricultural Research Service, Ft. Collins, CO.

Meyerson, L.A., Baron, J., Melillo, J.M., Naiman, R.J., O'Malley, R.I., Orians, G, ..., Sala, O.E., 2005. Aggregate measures of ecosystem services: can we take the pulse of nature? Front. Ecol. Environ. 3(1), 56-59.

Millennium Ecosystem Assessment (MA), 2005. Millennium Ecosystem Assessment: Living beyond our means-Natural assets and human well-being. World Resources Institute: Washington, D.C.

Moore, R., Tindall, C., 2005. An overview of the open modelling interface and environment (the OpenMI). Environ. Sci. Policy 8, 279-286.

Nellemann, C., 2009. The Environmental Food Crisis: The Environment's Role in Averting Future Food Crises: a UNEP Rapid Response Assessment. UNEP/Earthprint.

Nelson, E., Mendoza, G., Regetz, J., Polasky, S., Tallis, H., Cameron, D., ..., Shaw, M., 2009. Modeling multiple ecosystem services, biodiversity conservation, commodity production, and tradeoffs at landscape scales. Front. Ecol. Environ. 7(1), 4-11.

Nemecek, T., Kägi, T., 2007. Life Cycle Inventories of Swiss and European Agricultural Production Systems. Final report ecoinvent V2.0 No. 15a. Agroscope Reckenholz-Taenikon Research Station ART, Swiss Centre for Life Cycle Inventories, Zurich and Dübendorf, $\mathrm{CH}$, retrieved from: www.ecoinvent.ch.

Ogle, S.M., Breidt, F.J., Paustian, K., 2005. Agricultural management impacts on soil organic carbon storage under moist and dry climatic conditions of temperate and tropical regions. Biogeochemistry 72, 87-121.

Palmer, M.A., Febria, C.M., 2012. The heartbeat of ecosystems. Science 336(6807), 1393-1394.

Parra-López, C., Groot, J.C.J.J., Carmona-Torres, C., Rossing, W.A.H., 2008. Integrating public demands into model-based design for multifunctional agriculture: An application to intensive Dutch dairy landscapes. Ecol. Econ. 67, 538-551.

Parton, W.J., Schimel, D.S., Cole, C. V, Ojima, D.S., 1987. Analysis of factors controlling soil organic matter levels in Great Plains grasslands. Soil Sci. Soc. Am. J. 51, 1173-1179.

Pérez-Miñana, E., Krause, P.J., Thornton, J., 2012. Bayesian Networks for the management of greenhouse gas emissions in the British agricultural sector. Environ. Model. Softw. 35, 132148.

Pilgrim, E.S., Macleod, C.J., Blackwell, M.S., Bol, R., Hogan, D.V., Chadwick, D.R., ..., Firbank, L.G., 2010. Interactions Among Agricultural Production and Other Ecosystem Services Delivered from European Temperate Grassland Systems. Adv. Agron. 109, 117-148.

Pinto, M., Merino, P., Del Prado, A., Estavillo, J.M., Yamulki, S., Gebauer, G., Oenema, O., 2004. Increased emissions of nitric oxide and nitrous oxide following tillage of a perennial pasture. Nutr. Cycl. Agroecosys. 70(1), 13-22.

Polasky, S., 2008. What's Nature Done for You Lately : Measuring the Value of Ecosystem Services. Choices 23. 
Poppy, G.M., Chiotha, S., Eigenbrod, F., Harvey, C.A., Honzák, M., Hudson, M.D., ..., Dawson, T.P., 2014. Food security in a perfect storm: using the ecosystem services framework to increase understanding. Philos. T. Roy. Soc. B 369(1639), 20120288.

Potts, S.G., Biesmeijer, J.C., Kremen, C., Neumann, P., Schweiger, O., Kunin, W.E., 2010. Global pollinator declines: trends, impacts and drivers. Trends Ecol. Evol. 25, 345-353.

Potschin, M.B., Haines-Young, R.H., 2011. Ecosystem services: Exploring a geographical perspective. Prog. Phys. Geogr. 35, 575-594.

Power, A.G., 2010. Ecosystem services and agriculture: tradeoffs and synergies. Philos. Trans. R. Soc. B Biol. Sci. 365, 2959-2971.

Pretty, J.N., Noble, A.D., Bossio, D., Dixon, J., Hine, R.E., Penning de Vries, F.W.T., Morison, J.I.L., 2006. Resource-Conserving Agriculture Increases Yields in Developing Countries. Environmental Science \& Technology 40, 1114-1119.

Raudsepp-Hearne, C., Peterson, G.D., Bennett, E.M., 2010. Ecosystem service bundles for analyzing tradeoffs in diverse landscapes. Proc. Natl. Acad. Sci. 107, 5242-5247.

Ravishankara, A.R., Daniel, J.S., Portmann, R.W., 2009. Nitrous oxide (N2O): The dominant ozonedepleting substance emitted in the 21st century. Science 326(5949), 123-125.

Richardson, R.B., 2010. Ecosystem services and food security: Economic perspectives on environmental sustainability. Sustainability 2, 3520-3548.

Ritchie, J.T., Godwin, D.C., Otter-Nacke, S., 1986. CERES-Wheat: A simulation model of wheat growth and development, CERES Model description. Dep. Crop Soil Sci., Michigan State Univ., East Lansing, MI.

Ruhl, J.B., Kraft, S.E., Lant, C.L., 2007. The law and policy of ecosystem services. Cambridge Univ Press.

Sanderman, J., Farquharson, R., Baldock, J., 2009. Soil carbon sequestration potential: a review for Australian agriculture.

Schröder, B., 2006. Pattern, process, and function in landscape ecology and catchment hydrology-how can quantitative landscape ecology support predictions in ungauged basins? Hydrol. Earth Syst. Sci. 10, 967-979.

Sharpley, A., Foy, B., Withers, P., 2000. Practical and innovative measures for the control of agricultural phosphorus losses to water: an overview. J. Environ. Qual. 29, 1-9.

Simmhan, Y.L., Plale, B., Gannon, D., 2005. A survey of data provenance in e-science. SIGMOD Rec 34, 31-36.

Smith, P., Powlson, D., Glendining, M., Smith, J.O., 1997. Potential for carbon sequestration in European soils: Preliminary estimates for five scenarios using results from long-term experiments. Global Change Biology 3, 67-79.

Smith, P., Martino, D., Cai, Z., Gwary, D., Janzen, H., Kumar, P., ..., O'Mara, F., Rice, C., 2007. Policy and technological constraints to implementation of greenhouse gas mitigation options in agriculture. Agriculture, Ecosystems \& Environment 118, 6-28.

Steinfeld, H., Gerber, P., Wassenaar, T., Castel, V., Rosales, M., De Haan, C., 2006. Livestock's long shadow. FAO Rome.

Sun, Z., Müller, D., 2013. A framework for modeling payments for ecosystem services with agentbased models, Bayesian belief networks and opinion dynamics models. Environ. Model. Softw. 45, 15-28.

Sutton, M.A., Bleeker, A., Howard, C.M., Bekunda, M., Grizzetti, B., de Vries, W., ..., Zhang F.S., 2013. Our Nutrient World: The challenge to produce more food and energy with less pollution. Global Overview of Nutrient Management. Centre for Ecology and Hydrology.

Swinton, S.M., Lupi, F., Robertson, G.P., Hamilton, S. K., 2007. Ecosystem services and agriculture: cultivating agricultural ecosystems for diverse benefits. Ecol. Econ. 64(2), 245-252.

Tallis, H., Kareiva, P., Marvier, M., Chang, A., 2008. An ecosystem services framework to support both practical conservation and economic development. Proc. Natl. Acad. Sci. 105, 94579464. 
Tallis, H., Polasky, S., 2009. Mapping and valuing ecosystem services as an approach for conservation and natural-resource management. Ann. N. Y. Acad. Sci. 1162, 265-283.

TEEB, 2010. The Economics of Ecosystems and Biodiversity: Mainstreaming the Economics of Nature: A synthesis of the approach, conclusions and recommendations of TEEB.

Thiaw, I., Kumar, P., Yashiro, M., Molinero, C., 2011. Food and ecological security: identifying synergy and trade-offs. UNEP Policy Series: Ecosyst. Manage. 4, 1-12.

UN, 2013. UN World Population Prospects: The 2012 Revision, Key Findings and Advance Tables United Nations, Department of Economic and Social Affairs, Population Division.

Van Keulen, H., Aarts, H.F.M., Habekotté, B., Van der Meer, H.G., Spiertz, J.H.J., 2000. Soil-plantanimal relations in nutrient cycling: the case of dairy farming system "De Marke". Eur. J. Agron. 13, 245-261.

Verhulst, N., Govaerts, B., Verachtert, E., Castellanos-Navarrete, A., Mezzalama, M., Wall, P., ..., Sayre, K.D., 2010. Conservation agriculture, improving soil quality for sustainable production systems. Adv. Soil S., 1799267585, 137-208.

Vermeulen, S., Campbell, B., Ingram, J., 2012. Climate Change and Food Systems Annu. Rev. Environ. Resour. 37, 195-222.

Villa, F., 2007. A semantic framework and software design to enable the transparent integration, reorganization and discovery of natural systems knowledge. J. Intell. Inf. Syst. 29, 79-96.

Villa, F., 2009. Semantically driven meta-modelling: automating model construction in an environmental decision support system for the assessment of ecosystem services flows, in: Environ. Sci. Eng. Springer, 23-36.

Villa, F., Athanasiadis, I.N., Rizzoli, A.E., 2009. Modelling with knowledge: A review of emerging semantic approaches to environmental modelling. Environ. Model. Softw. 24, 577-587.

Villa, F., Bagstad, K.J., Voigt, B., Johnson, G., Portela, R., Honzák, M., Batker, D., 2014. A methodology for adaptable and robust ecosystem services assessment. PloS one, 9(3), e91001.

Vitousek, P.M., Aber, J.D., Howarth, R.W., Likens,G.E., Matson, P.A., Schindler, D.W., Schlesinger, W.H., Tilman, D.G., 1997. Human alteration of the Global Nitrogen Cycle: Sources and Consequences. Ecol. Appl. 7, 737-750.

Wallace, K.J., 2007. Classification of ecosystem services: Problems and solutions. Biol. Conserv. 139, 235-246.

Wardlaw, I.F.,Wrigley, C.W., 1994. Heat Tolerance in Temperate Cereals: an Overview. Australian Journal of Plant Physiology 21(6), $695-703$.

Williams, J.R., Renard, K.G., Follett, R.F., Stewart, B.A., 1985. Assessments of soil erosion and crop productivity with process models (EPIC). Soil Eros. Crop Product., 67-103. 